\title{
Strategies to Enhance the Competitiveness of Malaysia Haulage Operators at Bukit Kayu Hitam-Sadao, Thailand Border in Facing the Establishment of Asean Economic Community (AEC)
}

Shahrin Nasir, Mohd Hafiz Zulfakar, Muhamad Aziyan Hussim, Mohd Faiz Hakim Husain

To Link this Article: http://dx.doi.org/10.6007/IJARAFMS/v11-i4/11590 DOI:10.6007/IJARAFMS /v11-i4/11590

Received: 16 October 2021, Revised: 17 November 2021, Accepted: 29 November 2021

Published Online: 12 December 2021

In-Text Citation: (Nasir et al., 2021)

To Cite this Article: Nasir, S., Zulfakar, M. H., Hussim, M. A., \& Husain, M. F. H. (2021). Strategies to Enhance the Competitiveness of Malaysia Haulage Operators at Bukit Kayu Hitam-Sadao, Thailand Border in Facing the Establishment of Asean Economic Community (AEC). International Journal of Academic Research in Accounting Finance and Management Sciences, 11(4), 1-9.

Copyright: @ 2021 The Author(s)

Published by Human Resource Management Academic Research Society (www.hrmars.com)

This article is published under the Creative Commons Attribution (CC BY 4.0) license. Anyone may reproduce, distribute, translate and create derivative works of this article (for both commercial and non-commercial purposes), subject to full attribution to the original publication and authors. The full terms of this license may be seen at: http://creativecommons.org/licences/by/4.0/legalcode

Vol. 11, No. 4, 2021, Pg. 1 - 9 


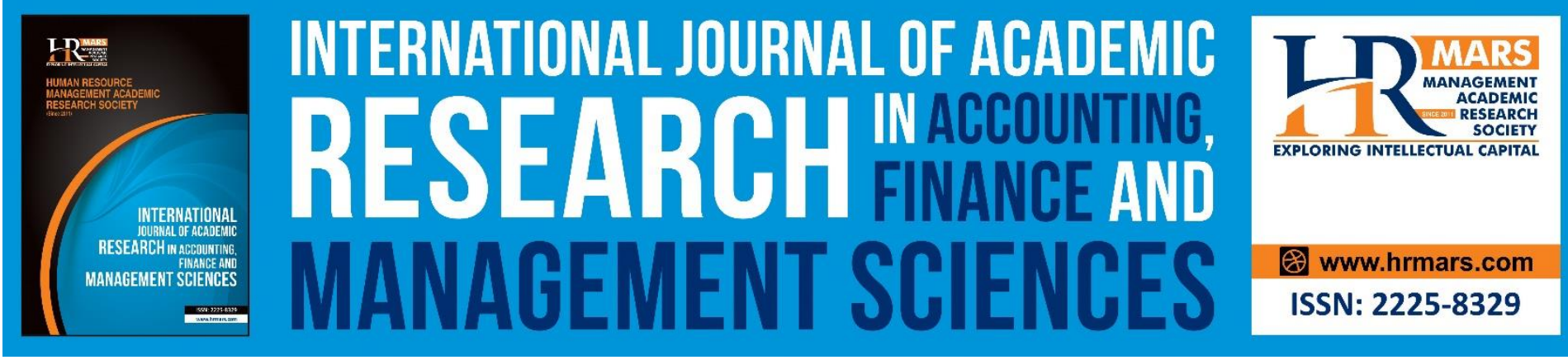

\title{
Strategies to Enhance the Competitiveness of Malaysia Haulage Operators at Bukit Kayu Hitam- Sadao, Thailand Border in Facing the Establishment of Asean Economic Community (AEC)
}

\author{
Shahrin Nasir \& Mohd Hafiz Zulfakar \\ Faculty of Business and Management, Universiti Teknologi MARA, Puncak Alam Campus \\ Email: shahrin378@uitm.edu.my \& mohdhafiz@uitm.edu.my
}

\author{
Muhamad Aziyan Hussim \\ Ministry of Transport, Malaysia \\ Email: aziyanhussim@gmail.com \\ Mohd Faiz Hakim Husain \\ Sufi Group Sdn Bhd \\ Email: faizhakim.sufi@gmail.com
}

\begin{abstract}
The implementation of ASEAN Economic Community (AEC) has given some impact towards the cross-border activities for ASEAN countries. Competitiveness, single market, cross border logistics have been the main highlight for the haulage operators that provide a cross border service between Malaysia and Thailand. This paper is discussing the strategies that need to be taken by the government and haulage operators in making Malaysia especially Bukit Kayu Hitam as the logistics hub between Malaysia and Thailand. Malaysia needs to upgrade its Customs, Immigration and Quarantine (CIQ) Complex facilities, Information Technology investment and address the talent issue for drivers for Malaysia to prepare facing AEC.
\end{abstract}

Keywords: AEC, Competitiveness, Cross-Border, Haulage Operators

\section{Introduction}

ASEAN Economic Community (AEC) can define as a single base market and production. The main components of AEC are: Free flow of goods, Free flow of services, Free flow of investments, Free flow of capital and Free flow of skilled labor. The ultimate purpose of AEC is to objective to remove the Non-Tariff Barriers (NTB). This move is expected to enhance the trade facilitation, increase the capabilities of border activities, and fasten the growth of haulage industry in the ASEAN region. As an example, the container haulage industry should 
MANAGEMENT SCIENCES

Vol. 11, No. 3, 2021, E-ISSN: 2225-8329 @ 2021 HRMARS

be given the rights to provide services to any ASEAN countries and at the same time following the domestics regulations of the respective countries. The establishment of AEC, it would be able to increase the demand for logistics services in Malaysia since there will be no restriction with inter countries movement, but the needs of unrestricted customs procedures must be in place. Not only that, the regulations on road network and reduced tariff also need to be harmonized. AEC will assist the economic integration, where ASEAN countries could appreciate the declining in trade barriers and enhancing the mobility of workforce which will accelerate the average growth of the logistics industry. To ensure the national strategic competitive advantage, effective management of cross borders haulage companies need to be the main focal point. Since AEC will change the operations of cross-borders activities, it is critical to ensure that Malaysia road haulage operators to be ready to face competitive services from neighboring countries. To support the road haulage operators, the government agencies also need to enhance its capabilities to ensure that the cross-border activities could increase the efficiency of Malaysia road haulage operators. Upgrading the cross-border infrastructure to the latest technology would assist the road haulage operators to operate competitively.

\section{Literature Review}

\section{Globalisation and ASEAN Economic Community (AEC)}

Taking advantage of competitive labor cost, energy cost, raw materials cost, land cost and capital costs are closely related to source for goods and services globally. Palmer (2013) has explained globalization as the process of removing the restrictions on cross borders movements and integrating the complex global productions system. Another definition of globalization is historical process of increasing international economic integration through the foreign direct investment, eliminating the barriers to trade and enhanced the capital flows, migration and also the knowledge transfer. Minford (2011). In other words, globalization means that companies that could produce and sell the same thing, the identical way and everywhere in the world. Levitt (2018) The development of globalization has increased the convergence of global preferences which has led into aggressive competition. This has urged many companies to enhance the market share and started to serve many new countries.

With ASEAN is set to be a single market where would enable the free flow of goods, services, investment, skilled labor and even capital between its member countries. This is in accordance with AEC blueprint. To be part of the AEC, Malaysia has introduced a few measures which parallel with the liberalization and deregulations initiatives in the logistics industry. Malaysia is positioning itself to be one of the most interesting market and the most influential logistics hub in the Asia-Pacific region. To support the successful of globalization initiatives, the must needed collaboration between agencies in cross border management which include customs, immigration, standards, sanitary, transport, veterinary and other related agencies are vital to ensure Malaysia are ahead on improving its cross-border management and activities. It is important for a comprehensive approach in improving ethe goods clearance process which required an efficient cooperation between several crossborder management agencies. More systematic and technological ways in adhering to the regulations has become critical in handling the rapid enhancement of logistics activities. 
MANAGEMENT SCIENCES

Vol. 11, No. 3, 2021, E-ISSN: 2225-8329 @ 2021 HRMARS

\section{Cross Border Logistics}

The logistics activities in cross-border management involves complicated operations which being handle by private firms such as the road haulage, warehouse, border clearance and even the system for payment. The efficiency of those services would highly be depending on the efficient activities by the government services and the policies which govern the logistics infrastructure for the global trade. The efficiency of cross border logistics activities very much depends on efficiency of government services and related policies that provide the logistics infrastructure for global trade. Shepherd (2014). Malaysia logistics industry potential to excel age huge with the implementation of $A E C$, so many improvements need to in place for the logistics industry to grow. The continuous improvements for the industry would enable the logistics industry to handle bigger volume of cargo, reducing the lead time of delivery to various supply chain and reducing the cost of delivery.

\section{Cross Border Haulage Operators Competitiveness Measurement}

Despite the positive growth of the logistics industry in Malaysia, there is little attention been devoted to the competitiveness of Malaysian haulage operators including assessing readiness of the cross border haulage service industry in facing AEC. Zaid and Shah 2017. Based on the Logistics Performance Index (LPI) 2018 by the World Bank. LPI (2018) Malaysia was position ate number 41, declined from the position of 32 in year 2016. Singapore was still the best position for ASEAN countries. Singapore was ranked no 7 under LPI. Among ASEAN members, Malaysia ranked at 4th place behind Singapore, Thailand (32) and Vietnam (39) but ahead of Indonesia (46). LPI is an assessment conducted by the World Bank every two years. The main components of the assessment are a) efficiency of the clearance process; b) quality of trade and transport related infrastructure; c) ease of arranging competitively priced shipments; d) competence and quality of logistics services; e) ability to track and trace consignments and f) timeliness of shipments in reaching destination within the scheduled or expected delivery time. A nation's competitiveness depends on the capacity of its industry to innovate and upgrade. Companies gain advantage against the world's best competitors because of pressure and challenge (Porter, 1990). The concept of competitiveness is multi-dimensional. There is different level of competitiveness. This could include the view of a country, industry, and organization level. From the firms' perspectives, competitiveness can be defined as:

- The firm ability to export or provide services to a range of countries without special dealings.

- $\quad$ The firm ability to engage in foreign direct investment (FDI) using local assets and skills.

- The firm ability to operate globally with the similar standards in terms of cost, service level, business processes, etc.; and

- The firm ability to earn beyond normal gain in a competitive market. Balzaravičienè and Pilinkienè (2012)

To evaluate the logistics performance, development of a conceptual framework is essential. This would enable to analyze the logistics performance in 4 different indicators. Aramyan et al (2007). Efficiency is the first indicator which measuring the resources utilizations rate. The components of this indicators usually focusing on the logistics process for instance the costs of distributions and the number of inventories held. Flexibility is the second indicator which include the capability of the firms to response to any unnecessary changes during the delivery of the logistics services. It also includes if the firm can handle any abnormal request by the customers. The third indicator is responsiveness which focusing on the shortest response time 
MANAGEMENT SCIENCES

Vol. 11, No. 3, 2021, E-ISSN: 2225-8329 @ 2021 HRMARS

in dealing with customer request and demand. The final indicator is quality which represents a specific supply chain criteria for example shelf life and product safety.

\section{Competitive Advantage Through Logistics}

One of the important factors in determining a country competitiveness in global market which focusing on the import and export growth is the efficiency of the logistics services, since it enables companies to increase their productivity level. Malaysia has targeted to become a logistics hub in the region to strengthen it economic position in the region. Malaysia must achieve that since many international corporations are putting Malaysia as an ASEAN base production. Excellent logistics services will assist the country development and ensuring the country to be more competitive and attracting foreign direct investment. With good logistics service performance, countries could enhance its trade, so that firm and customers could enjoy excellent quality of services with lower price. Arvis et al (2014) To create a seamless connectivity for the flow of cargo, Malaysia has emphasized in developing an integrated logistics and enhancing the tools for trade facilitation. EPU (2015) A few strategies have been created which include firming up the institutional and regulatory framework, building more efficient freight infrastructure, implementing new technology in the supply chain, and enhancing the capabilities of the logistics providers.

\section{Competitiveness Indicators}

Many organizations have position measuring competitiveness as an essential element the development process. Many performances indicators model has been produced and used in several organizations. Krauth et al (2005). Neely et al (2015) has indicated competitiveness measurement as a metric applied to quantify the efficiency or effectiveness of any tasks. However, defining competitiveness measurement has been a challenging task since the objectives and goals are varies from one organization to another (Mentzer and Konrad 1991). Table 1 indicate the a few examples of competitive advantage indicators.

Table 1 : Fundamental Factors Contributing To Competitiveness Advantage

\begin{tabular}{ll}
\hline Factors & Contributing Factors \\
\hline Operational Efficiency & $\begin{array}{l}\text { - Transport Infrastructure } \\
\text { - Human Capital } \\
\text { - Innovation }\end{array}$ \\
Information Efficiency & $\begin{array}{l}\text { - Supply Chain Management } \\
\text { - Trace \& Track Facility } \\
\text { - Electronic Data Interchange } \\
\end{array}$ \\
& AbDI) \\
Service Responsiveness & $\begin{array}{l}\text { changes of situations \& well as } \\
\text { customer needs }\end{array}$ \\
& Ability to achieve completion \\
Service Collaboration & of necessary activities \\
\hline
\end{tabular}

\section{Methodology}

Qualitative approach was used to conduct this study. Interview was the main instruments for the data collection. Interview is the main method to gain knowledge, experience, and views. Nasir (2014). To select the informants for this research was very challenging since the number 
MANAGEMENT SCIENCES

Vol. 11, No. 3, 2021, E-ISSN: 2225-8329 @ 2021 HRMARS

of cross-border haulage companies that can be interviewed were limited. To obtain all the required data the snowball sampling was implemented in selecting the informants.(Nasir et al 2021) One of the benefits of snowballing technique would help the researcher to get data from the right informants since it involves referring process. Even though, it still required some planning in choosing the informants, but the process can be simplified. The drawback of this techniques was the researcher was not able to control the informants for the study since the informants would be defending on the referral from the previous informants. Hendricks \& Blanken (1992). For this study, 7 interviews were conducted. The interviews were conducted at the informant's premises and each interview took between 1 to 2 hours. The interviews were recorded so that detail transcribing process can be done. The main goal of interview is to obtain responses relevant to the research study. The study is conducted at the cross-border facilities at Bukit Kayu Hitam. It is the border between Malaysia and Thailand Informants Profile

\begin{tabular}{|c|c|c|c|}
\hline No & Respondents & Experience & $\begin{array}{l}\text { Sector/ } \\
\text { Industry }\end{array}$ \\
\hline 1 & $\begin{array}{l}\text { Haulier Associations } \\
\text { representative }\end{array}$ & 22 Years & Association \\
\hline 2 & Manager & 11 Years & $\begin{array}{l}\text { Haulage } \\
\text { Operator }\end{array}$ \\
\hline 3 & Senior Manager & 12 Years & $\begin{array}{l}\text { Haulage } \\
\text { Operator }\end{array}$ \\
\hline 4 & Senior Manager & 12 Years & $\begin{array}{l}\text { Haulage } \\
\text { Operator }\end{array}$ \\
\hline 5 & $\begin{array}{lr}\text { Senior } & \text { Officer, } \\
\text { Ministry } & \text { of } \\
\text { Transport } & \end{array}$ & 17 Years & $\begin{array}{l}\text { Government } \\
\text { Agency }\end{array}$ \\
\hline 6 & $\begin{array}{l}\text { Officer, Ministry of } \\
\text { International Trade } \\
\text { \& Industry }\end{array}$ & 6 Years & $\begin{array}{l}\text { Government } \\
\text { Agency }\end{array}$ \\
\hline 7 & $\begin{array}{l}\text { Senior } \quad \text { Customs } \\
\text { Officer, Custom } \\
\text { Department }\end{array}$ & 22 Years & $\begin{array}{l}\text { Government } \\
\text { Agency }\end{array}$ \\
\hline
\end{tabular}

\section{Strategies to Support the Efficiency of Bukit Kayu Hitam in Cross Border Management Upgrading the Customs, Immigration and Quarantine (CIQ) Complex and Information Technology Infrastructure}

Cross border management between Malaysia and Thailand at Bukit Hitam has been indicated as inefficient operation. Two main factors that contributes towards of the inefficiency are the old facilities at the Customs, Immigration and Quarantine (CIQ) premises and the less usage of information technology in managing the cross-border activities. The number of trucks expected to pass the CIQ Bukit Kayu Hitam are between 400 to 500 daily. The inefficiency operation issue at the CIQ Complex has led to the problem of hundreds of haulage trucks stranded overnight at the border waiting for border clearance. Generally, many haulage operators did not invest in upgrading their information technology of the organization. The only investment made by them is the track and trace facilities which enables them to track the movement of their prime movers for the benefits of their customers. 
MANAGEMENT SCIENCES

Vol. 11, No. 3, 2021, E-ISSN: 2225-8329 @ 2021 HRMARS

For Bukit Kayu Hitam to be establish as an effective and efficient cross-border hub, a few new investments for a new $\mathrm{CIQ}$ facilities need to be provided. The CIQ need to have multiple entries and inspection for trucks movement. Apart from that, a special location for swapping the trailers need to be constructed to avoid the congestion at the border. To assists the smooth flow of non-duty item and empty truck movement dedicated lane for their movement should also be made available. With this new $\mathrm{ClQ}$ and the investment in new technology, Bukit Kayu Hitam, would be able positioned a freight or haulage hub between Malaysia and Thailand. The haulage operators have not invested in more advance communication system between the employees. Even though the operations at Bukit Kayu Hitam still depending on manual transactions, the haulage operators have started implementing the usage of electronic data interchange (EDI) and electronic fund transfer (EFT) for customs clearance. The government agencies also have started to utilize the usage of IT for handling the daily operations. New customs clearance system has been in place to replace the manual way of sealing and detecting the container movement. Under ASEAN Customs Transit System, has been developed to monitor the movement the transit movement by roads within the ASEAN countries. This is to complement the implementation of AEC. To ensure making Bukit Kayu Hitam to be the logistics hub between Malaysia and Thailand, the government agencies and the haulage operators must implement the total electronic commercial vehicle operations system. (CVO). This system would enable the supply chain integration to be efficient and adhering to the highest compliance to the stipulated regulations. This would make Bukit Kayu Hitam to remain competitive and efficient in managing cross-border movement. The CVO technology would enable the application of:

(a) Allowing the haulage trucks to pass the border crossing by using an electronic clearance technology. This is known as Automatic Identification Technologies (AIT)

(b) Paperless transactions between the trucks and other government agencies. The application would automate regulatory functions and increase data sharing capabilities between the local agencies.

(c) Screening the commercial trucks safety, size, weight and complying to regulation by using electronic screening.

(d) Automation for safety inspection system and assists the implementation of in-vehicle safety technologies. It would enhance drivers' safety

(e) Online freight monitoring which enables to do tracking, real-time communication. This would assist the management with more timely and accurate information which could enhance truck safety.

To achieve the success of CVO, it requires rigorous effort by the government and the haulage operators. The usage of the systems would enhance the competitive advantage for the Malaysian haulage operators. To accelerate the implementation of the system, some incentive could be given to the haulage operators that managed to

\section{Developing New Talent in Drivers}

Shortage of drivers has been a big challenge for haulage operators to face. With this issue it has affected the efficient of the industry. A few factors have contributed in shortage of drivers. Some of the significance problems are a) no career advancement and low salary; b) ineffective scheduling and management of drivers by the haulage operators; c) long working hours which made less time with families especially for a long-haul driver; d) strong 
MANAGEMENT SCIENCES

Vol. 11, No. 3, 2021, E-ISSN: 2225-8329 @ 2021 HRMARS

enforcement by enforcement agencies and e) many requirements needed before qualifying locals to apply for E-license for driving heavy vehicles. The training costs to apply for E-license is expensive which made it difficult for locals to apply.

To overcome the above challenges, a few strategies should be in place to ensure that the industry would not be lack of talent for the operators to sustain in the industry. The first approach is to change the perception that truck drivers is for low educated people. It might be difficult but there are a few companies that are working hard to uplift the truck driver's standard. The initiative might take a longer time to be executed. Secondly, the haulage operators need to portray the career in haulage industry is attractive and ensuring the working environment is acceptable. Even though it would be very challenging to make those changes. Thirdly, the stakeholders of the industry need to initiate a program with the driving institutes in targeting to produce a certain number of drivers with E-License yearly. The interested people can go through the program in a special rate. This could attract more people to apply and obtain the E-license. Fourth, the usage of new technology in human resource planning has become great importance for the haulage operators. It could assist the operators in enhancing the succession plan especially in development of drivers. Fifth, the government agencies involve in the industry need to review the current policy in accordance with development of technology. The right training for the commercial drivers must be available so that the drivers can keep pace with the technology changes. This will ensure that drivers are ready to adapt with any technology changes.

\section{Conclusion}

The implementation of AEC will provide the consumers with more varieties of services. They can access a more cheaper logistics services (logistics) and enjoy more extensive consumer protection. The haulage operators need to be ready especially with the usage of information technology for them to compete in a more competitive environment. They need to aware changes to be brought by AEC measures when they are fully implemented including challenges on expanding to other ASEAN member states (i.e: differences in commercial practices, legal systems). The establishment of AEC also need to urge the government to prepare Bukit Kayu Hitam to be the logistics hub for the cross-border movement between Malaysia and Thailand. New facilities at $\mathrm{CIQ}$ Complex must be the priority for the government to upgrade. Apart from the facilities, the government also should assist the haulage operators to prepare themselves with more talent to work as truck drivers in Malaysia. Without special assistance from the government, it would not accelerate the haulage operators to set up approaches to recruit more truck driver. These two strategies could contribute towards the success of Malaysia road haulage operators in competing which road haulage companies from other ASEAN countries.

\section{References}

Aramyan, L. H., Lansink, A. G. J. M. O., Van Der Vorst, J. G. A. J., \& Kooten, O. V. (2007). "Performance measurement in agri-food supply chains: A case study," Supply Chain Manag., vol. 12, no. 4, pp. 304-315

Arvis, J.-F., Saslavsky, D., Ojala, L., Shepherd, B., Busch, C., \& Raj, A. (2014). Connecting to Compete, Trade Logistics in the Global Economy," Worldbank, p. 72

Balzaravičienè, S., \& Pilinkienè, V. (2012), "Comparison and Review of Competitiveness Indexes: Towards the Eu Policy," Econ. Manag., vol. 17, no. 1, pp. 103-109, 
MANAGEMENT SCIENCES

Vol. 11, No. 3, 2021, E-ISSN: 2225-8329 @ 2021 HRMARS

Economic Planning Unit. (2015), "Unleashing Growth of Logistics and Enhancing Trade Facilitation, Prime Minister Department, Malaysia

Hendricks, V. M., \& Blanken, P. (1992). Snowball sampling: theoretical and practical considerations. , (August), pp.17-35

Krauth, E., Moonen, H., Popov, V., \& Schut, M. (2005), "Performance measurement and control in logistics service providing," Iceis 2005 - Artif. Intell. Decis. Support Syst., pp. 239-247.

Levitt's, T. (2018). Theory of Globalization. UKEssays. Retrieved from https://www.ukessays.com/essays/economics/the-global-economy.php?vref=1

Minford, P. (2011). A globalised Competitiveness commentary," Int. Bus., vol. 37, no. 2, pp. 176-178

Nasir, S (2014) Intermodal container transport logistics to andfrom Malaysian ports: Evaluation of Customer requirements and environmental effects. Doctoral thesis, Stockholm: KTH Royal Institute of Technology

Nasir, S., Zulfakar, M. H., \& Rahmat, A. K. (2021). Determinants of Preferred Export Logistics Gateway in Malaysia Halal Product Industry. International Journal of Academic Research in Accounting Finance and Management Sciences, 11(1), 489-498.

Neely, A., Mills, J., Platts, K., Richards, H., Gregory, M., Bourne, M., and Kennerley, M. (2015). "Performance measurement system design: developing and testing a process-based approach," Int. J. Oper. Prod. Manag., vol. 20, no. 10, pp. 1119-1145

Palmer T. G. (2003). "Globalization, Cosmopolitanism, and Personal Identity," Ethics Polit., no. 2, pp. 1-15, 2003

Porter, M. E. (1990), "The Competitive Advantage of Nations," Harv. Bus. Rev., vol. 68, pp. 7393.

Shepherd B. 2014, "Asia Pacific Trade Facilitation Forum: Background Paper for Session on Trade Logistics," vol. 1, pp. 1-32.

Zaid, Z. M., \& Shah, M. (2017). "Performance measurement in Malaysian container haulage industry: A critical evaluation," Eprints.Utm.My, pp. 1-14, 